\title{
The global survey of the electrical energy distribution system: a review
}

\author{
Archana S. Talhar, Sanjay B. Bodkhe \\ Department of Electrical Engineering, Shri Ramdeobaba College of Engineering and Management, India
}

\begin{tabular}{ll}
\hline \hline Article Info & ABSTRACT \\
\cline { 2 - 3 } Article history: & $\begin{array}{l}\text { This paper gives a review of energy scenario in India and other countries. } \\
\text { Today's demand of the world is to minimize greenhouse gas emissions, } \\
\text { during the production of electricity. Henceforth over the world, the } \\
\text { production of electrical power is changing by introducing abundantly } \\
\text { Revised Jan 3, 2019 } \\
\text { Accepted Jan 10,2019 } \\
\text { intermittent nature of sustainable power sources, the electrical power } \\
\text { network faces many problems, during the transmission and distribution of } \\
\text { electricity. For resolving these issues, Electrical Energy Storage (EES) is } \\
\text { acknowledged as supporting technology. This paper discusses about the }\end{array}$ \\
Global energy & $\begin{array}{l}\text { world electrical energy scenario with top renowned developed countries in } \\
\text { power generation and consumption. Contribution of traditional power } \\
\text { Global power generation } \\
\text { Greenhouse gas emissions } \\
\text { Power consumption } \\
\text { Sustainable energy } \\
\text { and wind. Worldwide Agencies are formed like International Energy Agency } \\
\text { (IEA), The Central Intelligence Agency, (CIS) etc. The main aim of these } \\
\text { agencies is to provide reliable, affordable and clean energy. This paper will } \\
\text { discuss about the regulatory authority and government policies/incentives } \\
\text { taken by different countries. At the end of this paper, author focuses on } \\
\text { obstacles in implementation, development and benefits of renewable energy. }\end{array}$
\end{tabular}

Copyright (C) 2019 Institute of Advanced Engineering and Science. All rights reserved.

Corresponding Author:

Archana S. Talhar,

Department of Electrical Engineering,

Nagpur University, Shri Ramdeobaba College of Engineering and Management,

Nagpur, India.

Email: archanabelge2@gmail.com

\section{INTRODUCTION}

Since the growth of any country depends on the growth of electricity, so the world's electricity generation has increased rapidly over the last few decades. From 2000 to 2016, the annual gross production of electricity increases at the rate of $2.9 \%$ per year and till the end of 2016 , reached to approximately 24,660TWh [1-2]. Similarly, the annual gross consumption increases by the rate of $3 \%$ per year which is approximately $21,190 \mathrm{TWh}$ till the end of 2016 [3-7]. The fossil fuel contributes around $80 \%$ of global electricity generation, biofuel contributes $10 \%$, nuclear energy contributes $5 \%$ and remaining $5 \%$ contributed by renewable energy sources [8-10]. The contribution of wind and solar electricity is increasing at the rate of $15.6 \%$ per year. In 2000 , the contribution was $0.56 \%$ of the total global electricity generation, whereas in 2016, it increased to 5.66\% [3-7]. The Intermittent and the unstable nature of renewable energy sources leads to mismatch between supply and demand. To minimize mismatch and to maintain stability, mostly load balancing carried out by fossil fuel power plants. Considering environmental aspects and to reduce $\mathrm{CO}_{2}$ emissions, the generation of electricity will progress by minimizing the use of fossil fuels and maximizing use of sustainable power sources. It's a major struggle to get the practical solutions, which includes Storage Management System (SMS), load scheduling via demand management, interconnection among external grids, etc. Electrical Energy Storage i.e. EES has been accepted as one of the most favorable approaches amongst all the possible solutions [8-9]. 
Under the umbrella of renewable energy, wind energy is growing slowly. In 2010, the wind power production of the world was $344.8 \mathrm{TWh}$. The countries contribute in a major power production by wind are United States (95.2TWh), China (55.5TWh), Spain (43.7TWh), Germany (36.5TWh), India (20.6TWh) and United Kingdom (10.2TWh). In year 2015 the worldwide installed capacity of wind power was 432,883MW. This is increasing at the rate of $17 \%$ per year [10-11]. Similarly, solar power is also rising in the world with the total installed PV capacity of $397 \mathrm{GW}$ with an additional capacity of $94 \mathrm{GW}$ in 2017 [12]. In recent years, it is seen that the renewable electricity market has an extraordinary growth; in fact, in the year 2016, it drives the world energy market. As costs are decreasing, wind and solar are becoming popular and also emerging as an alternative to fossil fuel. China maintains the 1st position; India also gradually moving to center stage. By 2022, a global electricity generation using sustainable power sources will grow by more than one-third to over $8,000 \mathrm{TW} / \mathrm{h}$. This is almost same as the total energy usage by China, India and Germany. The share of renewables in a power generation has increased by $24 \%$ in 2016 , and will reach $30 \%$ in 2022 [13]. In many countries, for utility-scale projects, the pattern is to move sustainable arrangements from government-set duties to competitive auctions with long-term power purchase agreements (PPAs). In developing countries, due to the increased competition, reimbursement levels for solar PV and wind projects has been reduced by $30-40 \%$ in just two years. e.g. India, Germany and Turkey. By 2017-22, almost half of the renewable electricity capacity expansion is expected to be driven by competitive auctions with PPAs [13]. Table 1, shows top 10 countries around the world with large electricity installed capacity (2015-16) [14].

Table 1. Countries with installed capacity

\begin{tabular}{clc}
\hline Sr. No. & Top Countries & $\begin{array}{r}\text { Electricity-installed generating } \\
\text { capacity (millions kW) }\end{array}$ \\
\hline 1 & China & 1646 \\
2 & United States & 1074 \\
3 & European Union & 9470 \\
4 & India & 308.8 \\
5 & Russia & 263.5 \\
6 & Japan & 322.2 \\
7 & Canada & 147.6 \\
8 & Germany & 204.1 \\
9 & Brazil & 155.6 \\
10 & France & 129.3 \\
\hline Source: Central Intelligence Agency 2016 [US]
\end{tabular}

\section{GLOBAL ENERGY SURVEY AT A GLANCE}

The International Energy Agency i.e. IEA, a self-coordinated organization, was built up in 1974. The main aim of IEA was to advance vitality security among its part nations, also to give definitive research and investigation on approaches to guarantee moderate, steady and clean vitality. The Agency's objectives are [13]:

a. To ensure the access of the member countries for the reasonable, solid and adequate supply of all types of vitality.

b. To help supportable vitality policies which guarantees financial development and environmental protection as far as decreasing $\mathrm{CO}_{2}$ emissions which add to environmental change.

c. By collection and analysis of the energy data transparency of the international market improved.

d. To safeguard future energy supplies and minimize their environmental impact, support global collaboration on energy technology.

e. To scan for elective answers for worldwide vitality tests through exchanges \& commitment with countries which are not associated with IEA, industry, global organizations \& different partners.

In 2016, because of sharp cost diminishments and policy support, solar photovoltaics deployment flourished in China and around the globe. In [13], it was examined that, in the year 2016, renewables represented nearly two-third of the net power limit of $165 \mathrm{GW}$. It is expected that, from 2017 to 2022 , worldwide renewable capacity growth will grow by $43 \%$ i.e. $920 \mathrm{GW}$. China contributes around $40 \%$ of worldwide sustainable bulk growth. This is mostly focused by doubts about air contamination and capacity goals that were sketched out in the nation's 13th five-year plan. In fact, China already beat it's 2020 solar PV target, and suppose to exceed its wind goal in 2019. As an outcome of policy changes in China, the whole exercise is driven by a remarkable market element and by consistent technology cost reductions. In the same fashion, it is anticipated that, by 2022, the total solar PV volume around the globe, would achieve $740 \mathrm{GW}$. This is more than the collective power capacities of the countries like India and Japan. Major countries contributing in the electricity generation are discussed: 


\subsection{China}

To meet increasing need, China struggles to maintain electricity supply. Approximately $2 \%$ of the total population i.e. $1,200,000$ of China is still without electricity. In the past few years, after its reconstruction, the electricity market of China has grown massively. Here are some truths about the growth of the power sector in China [14]:

a. $1^{\text {st }}$ rank in world's population $1,379,302,771(2016)$.

b. Population growth at the rate of $0.41 \%$ annually.

c. The gross domestic production growth rate of 6.7-6.9\%.

d. $1^{\text {st }}$ country in the world in energy consumption as well as in the energy production.

e. $1^{\text {st }}$ in electricity export: 18.91 billion $\mathrm{kWh}(2016)$.

1) Regulatory authorities are [15]:

a. National People's Congress (NPC): This is the legislative body. It is having the rights to communicate laws.

b. State Council: It assumes the liability for representing the NPC's laws and approaches, and instituting directions under the legitimate structure.

c. National Energy Commission (NEC): It administer vitality matters.

d. National Development and Reform Commission (NDRC): A large scale management administration organization under the State Council.National Energy Administration (NEA): A unit under the NDRC and commences the daily work of the NEC.

As per China's New Energy Power Report (2013), fossil fuel, nuclear source and renewable vitality are the main sources of power generation. From 2013 to 2017 the contribution of sources in electricity generation is shown in Figure 1.

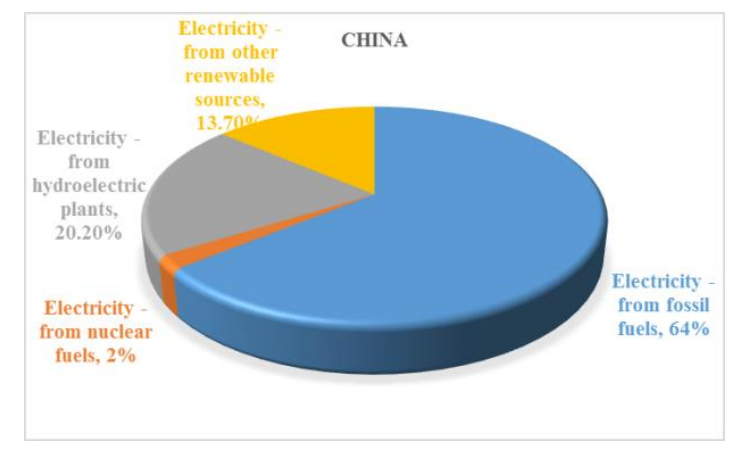

Figure 1. Contribution of sources in generation of electricity in China

2) Government policies/incentives [15]:

a. The primary focus of the state is to develop clean renewable energy, which includes wind power, solar energy and biomass energy.

b. States are encouraged to accept advanced technologies for observing and controlling the utilization of energy and to utilize clean coal.

c. State budgets are equipped with renewable energy development funds. Also can grant tax benefits, subsidy and can offer loans for renewable energy.

\subsection{India}

In spite of the fact that India has a substantial verity of sustainable and non-sustainable power source assets, India suffers from lack of generation, transmission and distribution of electricity. The electricity is the backbone for the development. With a specific goal to enhance the power system, the Government of India has made different enterprises like State Electricity Boards (SEB), National Thermal Power Corporation (NTPC), National Hydro-Electric Power Corporation (NHPC) and Power Grid Corporation Limited (PGCL) [16]. Few realities of the power sector in India [14]:

a. $2^{\text {nd }}$ rank in world's population $1,281,935,911$ (July-2017).

b. $1.17 \%$ per year population growth rate.

c. The GDP growth rate of $6.7-8 \%$.

d. $4^{\text {th }}$ in the energy production of the world.

e. Rank $4^{\text {th }}$ in the energy consumption.

f. $4^{\text {th }}$ in Carbon dioxide emissions from consumption of energy. 
1) Regulatory authorities are [17]:

a. The Ministry of Power (MoP): To monitor, to improve the guideline and improvement of power sector.

b. Ministry of New and Renewable Energy (MNRE): The primary motive of MNRE is to search for regulation of new and sustainable power source.

c. Central Electricity Regulatory Commission (CERC): CERC is accountable for the following: 1) Regulating the tariff of generating stations or those involved in generating or supplying wherever required. 2) Regulating between state power transmission. 3) Resolving disagreements amongst generating firms and licensees.

d. State Electricity Regulatory Commission (SERC): The main aim of SERC is to control intra-state transmission and supply of power within the authority of each state.

e. Central Electricity Authority (CEA): The CEA is accountable for the technical synchronization and management of programs/policies and is also additionally endowed with various legal capacities under the Electricity Act.

f. Appellate Tribunal for Electricity (APTEL): APTEL has been set up as an appellate body for offers against requests of commissions (CERC and SERCs).

g. National Load Dispatch Centre: The National Load Dispatch Centre schedules as well as dispatches power over inter-regional links in accordance with grid standards.

h. Regional Load Dispatch Centre: All regions including northern, eastern, north eastern, southern and western has its own regional dispatch center. These are responsible for the incorporated activity of the power system in its own region.

2) Government policies/incentives [18]:

a. Foreign Direct Investment (FDI) Policy: Under automatic route for projects of renewable power generation and distribution, $100 \%$ FDI is permitted.

b. FDI Equity Inflow: During April 2014 - December 2016, total FDI equity inflow in the nonconventional energy sector was USD 2.05 billion.

c. To promote sustainable power source projects, The Government has given an entire host of monetary and fiscal incentives. Over a time of five years (up to 2019-20), Under National Solar Mission (NSM), INR 5,000 crore has been sanctioned for execution of Grid Connected Rooftops frameworks. This will help installation of 4,200MW Solar Rooftop systems in the nation in the following five years (December 2015).

By the end of 2022, Government is focusing to enhance the renewable energy capacity up to $175 \mathrm{GW}$. Bifurcation would be $100 \mathrm{GW}$ by solar, $60 \mathrm{GW}$ by Wind, $10 \mathrm{GW}$ by biomass and $5 \mathrm{GW}$ by small hydro. India was ranked the top ten nations in the world investing in renewable energy by UN Environment Program's (UNEP) 'Global Trends in Renewable Energy Investment 2016’.

\subsection{Japan}

Electricity distribution in Japan is done by privately owned independent regional electric power. In 1952, nine electric power organizations built up the Federation of Electric Power Companies (FEPC) to advance smooth tasks within the industry [19]. As per Federation of Electric Power organizations of Japan, Electricity generation by fossil fuel is $84.6 \%, 9.6 \%$ of power by hydroelectric source, $4.7 \%$ from other inexhaustible sources and rest $1.1 \%$ from nuclear sources [16]. Here are some realities regarding the situation of the power sector in Japan [14]:

a. $10^{\text {th }}$ in the world's population $126,451,398$ (2017).

b. $0.21 \%$ per year Population growth rate.

c. $1-1.5 \%$ GDP growth rate.

d. $6^{\text {th }}$ largest energy producer of the world.

e. Rank $5^{\text {th }}$ in energy consumption.

f. Import and export of electricity is not possible because there is no transmission grid connection with neighboring counties.

1) Regulatory authorities are [20]:

a. Ministry of Economy, Trade and Industry (METI)

b. Agency for Natural Resources and Energy (ANRE)

c. Electricity and Gas Market Surveillance Commission (EGMSC)

d. Nuclear Regulation Authority (NRA).

e. Organization for Cross-regional Coordination of Transmission Operators, Japan (OCCTO)

f. Ministry of Environment (MOE)

g. Ministry of Health, Labour and Welfare (MHLW)

Int J Elec \& Comp Eng, Vol. 9, No. 4, August 2019 : 2247 - 2255 
2) Government policies/incentives [20]:

a. FIT mechanism was introduced by the Renewable Energy Act in Japan. METI regulates the procurement by electricity retailers, the purchase price and purchase period.

b. Subsidies and tax treatment are offered for combined heat and power (co-generation).

In light of the "Best Energy Mix Plan in FY 2030" distributed by METI on $28^{\text {th }}$ April 2015, Renewable vitality accounts just $4.7 \%$ of source of the power generation in 2015 , the administration anticipates that it will surpass $20 \%$ in 2030 .

\subsection{Germany}

The principle goal of German vitality regulation is to supply power which is secure, moderate, consumer-friendly, productive and environmentally sustainable. To satisfy this target, the German vitality approach advances the generation of power from sustainable power sources. Here are some realities regarding the situation of power sector in Germany [14]:

a. $19^{\text {th }}$ rank in the world's population $80,594,017$ (2017).

b. Population growth rate of $0.16 \%$ annually.

c. The GDP growth rate of $1.5-2.1 \%$.

d. $8^{\text {th }}$ largest energy producer of the world.

e. Rank $8^{\text {th }}$ in the energy consumption.

f. $7^{\text {th }}$ in Carbon dioxide emissions from consumption of energy.

1) Regulatory authorities are [21]:

a. Federal Network Agency (Bundesnetzagentur (BNetzA)).

b. State regulatory authorities (Landesregulierungsbehörde).

c. Federal Cartel Office (Bundeskartellamt (BKartA)).

d. Market Transparency Authority for Electricity and Gas (Markttransparenzstelle Strom und Gas (MTS)).

e. Federal Environment Agency (Umweltbundesamt (UBA)).

f. German Emission Trading Authority (Deutsche Emissionshandelsstelle (DEHSt)).

2) Government policies/incentives [21]:

a. Priority association with the grid (with the grid operator's commitment to improve, upgrade or grow the grid if required).

b. Priority access to the grid.

c. Fixed feed-in tariffs (or, alternatively, direct marketing including a market premium and administration expense).

\section{POWER SECTOR AND ISSUES}

The contribution of top countries of the world in energy production and consumption are mentation in Figure 2. Although many countries are participating in clean and green energy mission, but still $2-3 \%$ Populations in countries like China, India, and Brazil are still without electricity as shown in Table 2 [14].

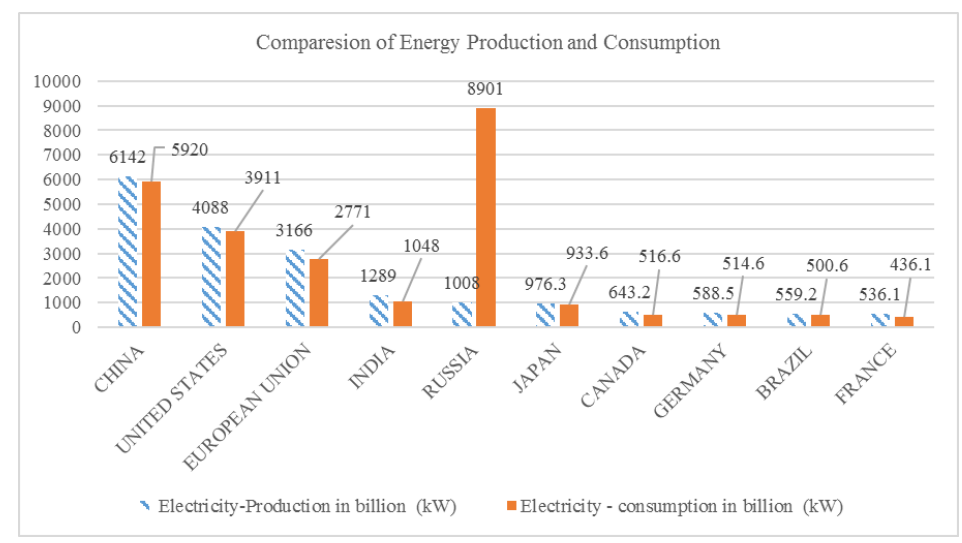

Figure 2. Energy production and consumption of top countries 


\begin{tabular}{cllcl}
\multicolumn{5}{c}{ Table 2. Population with and without electricity } \\
\hline \multirow{2}{*}{ Sr. No } & Top Countries & $\begin{array}{c}\text { Population } \\
\text { without electricity }\end{array}$ & $\begin{array}{c}\text { Electrification - } \\
\text { urban area }\end{array}$ & $\begin{array}{c}\text { Electrification - } \\
\text { rural area }\end{array}$ \\
\hline 1 & China & $1,200,000$ & $100 \%$ & $99.8 \%(2016)$ \\
2 & United States & Nil & $100 \%$ & $100 \%(2016)$ \\
3 & European Union & Nil & $100 \%$ & $100 \%(2016)$ \\
4 & India & $237,400,000$ & $98 \%$ & $70 \%(2013)$ \\
5 & Russia & Nil & $100 \%$ & $100 \%$ \\
6 & Japan & Nil & $100 \%$ & $100 \%$ \\
7 & Canada & Nil & $100 \%$ & $100 \%$ \\
8 & Germany & Nil & $100 \%$ & $100 \%$ \\
9 & Brazil & 800,000 & $100 \%$ & $97 \%(2013)$ \\
10 & France & Nil & $100 \%$ & $100 \%$ \\
\hline Source: Central Intelligence Agency 2016 [US] & &
\end{tabular}

Source: Central Intelligence Agency 2016 [US]

To meet the world's vast and developing power needs, there are numerous inadequacies. The major obstacles in the development of renewable energy in almost all countries in the world are discussed further [22-24]:

\subsection{Capital costs}

The very common hurdle in implementing renewable energy is capital cost. This includes the hardware installation cost of solar and wind farms. Since fuel is free and maintenance is minimal, solar and wind are cheap to work; however, can be costly to manufacture.

\subsection{Lack of knowledge}

Although solar energy becoming worldwide popular, there is lack of knowledge among the public. Existing engineers in the firms who are having knowledge are not willing to share it with the new joiners.

\subsection{Lack of infrastructure}

At present, the vast majority of organizations have no adequate framework for supporting sustainable power. For this, the organizations need to explicitly locate the regulatory acceptable sites with great assets and with access to transmission lines. Another obstruction is the interconnection of sustainable power source plants. On account of the substantial cost, few grid organizations are hesitant to associate the renewable energy plants.

\subsection{Supplier involvement}

Supplier involvement is a must for development of renewable energy. Expectations are prompt service, reliable, etc. The healthy competition among suppliers is benefitting industry. Getting a reliable renewable energy supplier is a difficult task. e.g. China is providing suppliers to Malaysia. But when the technical issue happens, suppliers are not easily available and reluctant to share knowledge. This could be because of the distance between the two countries and also because of the insecurity factor.

\subsection{Siting and transmission}

Decentralization offers few advantages and few drawbacks also. Siting includes the installation of wind turbines and solar farms. This requires remote open space. Also requires negotiations, contracts, permits, and community relations. This ultimately increases the installation costs of the farm. Transmission lines are not fully mature or upgraded to transmit the generated power to the consumer site. This requires finance, infrastructure. All wind and solar farms are not sited near old nuclear or fossil fuel power plants, so transmission of power from renewable plants is the biggest hurdle. This transmission of power requires a big setup which involved huge finance / capital. In short, the financing and the siting can be significant barriers for developers and customers.

\subsection{Structural overloading}

There are plenty of companies available in the market for the power generation, but all are not having advanced technology for storing and transmitting power from generation side to distribution side. Furthermore, because of lack of capital, numerous renewable power source plants are immature, which prompts insecurity in the power generation during transmission. 


\subsection{Aging power plants and transmission network}

Since the greater part of the power plants and transmission lines have been introduced long back; they have turned out to be old and wasteful. This is the main reason behind the low development and transmission rate in power generation. Old and wasteful plants and lines should be supplanted or redesigned and modernized to accomplish the power creation and demand target.

\section{BENEFITS OF CHANGING POWER SECTOR}

Due to the increase in the participation of renewable energy sources in electricity generation worldwide, following are benefits [22-24]:

\subsection{Less global warming}

Most of the renewable energy sources produce minimum global warming emissions. This includes emissions from each and every stage like assembling, establishment, activity, retiring. The global warming emissions associated with renewable energy are negligible.

\subsection{Improved public health}

The majority of medical problems like breathing issues, neurological harm, heart attacks, tumor, premature death and so forth are related with the air and water contamination which is discharged by coal and natural gas plants. However, renewable energy plants generate electricity with no air and water pollution.

\subsection{Inexhaustible energy}

The renewable energy sources i.e. wind, solar, hydro are abundantly available at free of cost and that also forever. It is intermittent in nature but abandently available globally.

\subsection{Jobs and other financial advantages}

In comparison to fossil fuel plants, which are capital demanding and regularly automated, the renewable energy industry is more labor exhaustive. Solar panels need labours for installation; wind farms require technicians for the maintenance. That means, for a renewable energy generation, more manpower is required as compared to fossil fuels. The United States, already supports thousands of jobs in the field of Renewable energy. Over 100,000 employees were recruited in the field of wind energy industry in 2016 in the variety of capacities. This includes built-up, project development, assembly and turbine installation, operations and maintenance, transportation and coordination, monetary, legal, and counseling services.

\subsection{Constant energy prices}

Currently renewable energy is facilitating with reasonable power across the world. In the future, this can help to stabilize energy prices. Although the initial infrastructure cost for renewable energy sources is high but running cost is very low. As a result, over the time, renewable energy prices can be very steady.

\section{CONCLUSION}

In this paper, a review of world power scenario is discussed. From 2000 to 2016, the world economy has grown very fast along with the world electricity market. To reduce greenhouse effects and with great respect for the environment, the growing economy has forced to use abundantly available renewable energy sources like wind, solar, and hydroelectric systems. Even though this development in supply, most of the countries in the world are still facing major challenges in providing electricity access to all households and are also struggling for improving reliability and quality of power supply. The major constraint is the shortage of capital resources and installation cost.

Although the renewable energy power generation is increasing worldwide, still there are many constraints in the successful implementation like lack of awareness, government policy, regulatory bodies, technological, social and financial barriers. So barriers and benefits of promoting renewable energy sources are also discussed.

\section{ACKNOWLEDGEMENTS}

Authors are thankful to the Organization and Dr. B. K. Mishra, Principal, Dr. Sandhya Save, H.O.D. Electronics of Thakur College of Engineering and Technology, Mumbai, India for their support. Also thankful to family members, Dr. Sangeeta Mishra and friends who have supported us along the way. 


\section{REFERENCES}

[1] Enerdata, "Energy Statistical Yearbook 2017," Retrieved May 18, 2018, url: https://yearbook.enerdata.net/totalenergy.html

[2] International Energy Agency (IEA), "Market Report Series, Renewables 2O17, Analysis and Forecasts to 2O22," Organisation for Economic Cooperation and Development (OECD), Publishing, Retrieved May 23, 2018, url:http://www.iea.org/Textbase/npsum/renew2017MRSsum.pdf.

[3] Total energy consumption, Acceleration in energy consumption in 2017, Retrieved May 18, 2018, url: https://yearbook.enerdata.net/total-energy/world-consumption-statistics.html.

[4] Total energy production, World energy production rebounded in 2017 (2.4\%), above its historical trend, Retrieved May 18, 2018, url: https://yearbook.enerdata.net/total-energy/world-energy-production.html.

[5] Renewable in electricity production share, 2017, Retrieved May 20, 2018, url: https://yearbook.enerdata.net/ renewables/renewable-in-electricity-production-share.html.

[6] Wind solar share electricity production, 2017, Retrieved May 20, 2018, url: https://yearbook.enerdata.net/ renewables/wind-solar-share-electricity-production.html.

[7] Electricity domestic consumption data, 2017, Retrieved May 22, 2018, url: https://yearbook.enerdata.net/ electricity/electricity-domestic-consumption-data.html.

[8] X. Luo, et al.,"Overview of current develpoment in electrical energy storgae technologies ans the application potential in power system operation," Journal of Applied Energy, pp. 511-536, 2015.

[9] BP Statistical Review of World Energy 2017, Retrieved May 22, 2018, url: https://www.bp.com/ content/dam/bp/en/corporate/pdf/energy-economics/statistical-review-2017/bp-statistical-review-of-world-energy2017-full-report.pdf.

[10] Global Wind Statistics 2011, Retrieved May 22, 2018, url: http://gwec.net/wp-content/uploads/2012/06/GWEC__Global_Wind_Statistics_2011.pdf

[11] Worldwide Electricity Production From Renewable Energy Sources: Stats and Figures Series: Thirteenth Inventory Edition 2011, Electricity Production From Wind Sources: Main Wind Power Producing Countries 2010, Retrieved June 1, 2018, url: https://en.wikipedia.org/wiki/World_energy_consumption

[12] Renewable capacity statistics 2018, International Renewable Energy Agency (IRENA), Abu Dhabi, "Data and Statistics-IRENA Resource," Retrieved May 5, 2018, url: http://www.irena.org/publications/2018/Mar/RenewableCapacity-Statistics-2018

[13] International Energy Agency (IEA), "Market Report Series, Renewable 2017," Executive Summery, Retrieved May 22, 2018, url: https://www.iea.org/Textbase/npsum/renew2017MRSsum.pdf

[14] Central Intelligence Agency [US], "Electricity Installed generating capacity," 2014. Retrieved May 22, 2018, url: https://www.cia.gov/library/publications/the-world-factbook/rankorder/2236rank.html

[15] W. Weidong, et al., "Electricity regulation in China: Overview," Energy and Natural Resoures Multi-Jurisdictional Guide 2014, Retrieved Augus 7, 2018, url: https://uk.practicallaw.thomsonreuters.com/1-524-4813?_lrTS= $20180807130345760 \&$ transitionType=Default\&contextData=(sc.Default $)$.

[16] A. Omer, et al., "Indian power system: Issues and Opportunities," International Journal of Advanced Research in Electrical, Electronics and Instrumentation Engineering, vol. 2, pp. 1089-1094, 2013.

[17] P.Bedi, et ai.,"Electricity regulation in India: Overview," Practical Law Country, Retrieved on May 22, 2018, url: https://uk.practicallaw.thomsonreuters.com/6-525-5272?transitionType=Default\&contextData=(sc.Default)

[18] Department of Indutsrial Policyand Promotion, Ministry of New and Renewable Energy (MNRE) "New Renewable Energy Sector," Achievement Report, Jan 18, 2017.

[19] Electricity Review Japan, The Federation of Electric Power Companies of Japan, 2016.

[20] T. Kobayashi, et al., "Electricity regulation in Japan: Overview," Energy and Natural Resoures Global Guide 2017, Retrieved August 7, 2018, url: https://www.fepc.or.jp/english/library/electricity_review_japan/_icsFiles/afieldfile/ 2016/08/24/2016ERJ_full.pdf

[21] U. Scholz, et al.,"Electricity regulation in Germany: Overview," Practical Law Country, Retrieved August 7, 2018, url: https://uk.practicallaw.thomsonreuters.com/5-524-0808?transitionType=Default\&contextData=(sc.Default).

[22] Y. Fernandoa, et al., "Challenges in implementing renewable energy supply chain in service economy era," Industrial Engineering and Service Science, IESS, Procedia Manufacturing, vol. 4, pp. 454-460, 2015.

[23] Union of Concerned Scientists [US], "Benefits of Renewable Energy, Science for a Healthy Planet and Safer World," revised on December 2017, Retrieved May 31, 2018, url: https://www.ucsusa.org/clean-energy/renewableenergy/public-benefits-of-renewable power\#.WxeKXIUzbIV

[24] Union of Concerned Scientists [US], "Barriers to Renewable Energy, Science for a Healthy Planet and Safer World," revised on December 2017. Retrieved May 31, 2018, url: https://www.ucsusa.org/clean-energy/renewableenergy/barriers-to-renewable-energy\#.WxeLb1UzbIU 


\section{BIOGRAPHIES OF AUTHORS}

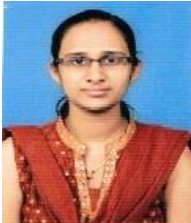

Archana S. Talhar obtained B.E. degree in 2005 from Rashtrasant Tukadoji Maharaj Nagpur University, Nagpur, India. She completed M.Tech in Integrated Power Systems in 2007 from G.H.Raisoni College of Engineering, Nagpur, India. Her areas of interest are Smart Grid, Renewable Energy, Control Systems, Power Electronics. Currently she is pursuing Phd from Shri Ramdeobaba College of Engineering and Management, Nagpur, under Nagpur University. She is member of Indian Society for Technical Education (ISTE).

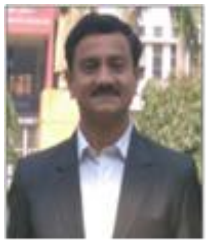

Sanjay B. Bodkhe has completed his graduation in 1990 from Walchand College of Engineering, Sangli and M.Tech in Integrated Power Systems from Visvesvaraya National Institute of Technology, Nagpur in 1996. He has done his PhD from Visvesvaraya National Institute of Technology, Nagpur in the year 2011. Currently he is working as a Dean Academic in Ramdeobaba college of Engineering, Nagpur, Maharashtra. He has authored two books on electrical engineering and published more than thirty research papers in reputed journals and conferences. His research interests include Electrical Machines, Power Electronics, Power Electronics and Drives, Renewable Energy. He is member of Indian Water works Association (IWWA), Institution of Engineers (India)(IE(I)), International Association of Environmental Management (IAEM) and Indian Society for Technical Education (ISTE). 